\title{
Emerging Viral Infectious Diseases-Peril to Human Health
}

\author{
Kaur S* and Jansi K \\ MSc Nursing, Akal College of Nursing, Eternal University, Baru Sahib, HP, India \\ *Corresponding author: Simarjeet Kaur, MSc Nursing, Akal College of Nursing, Eternal \\ University, Baru Sahib, HP, India, Tel: 8427016084; Email: simarjeet3011@gmail.com
}

\section{Review Article}

Volume 2 Issue 4

Received Date: March 14, 2018

Published Date: April 05, 2018

\section{Abstract}

In recent years there has been increasing attention towards the changing patterns of infectious diseases. In particular, the factors that lead to increases in the rates of these so-called 'emerging infectious diseases' (EIDs) has focused primarily on the role of human activities, such as land use changes, population growth, increased contacts with wild animal reservoirs and the degradation of health care resources. Emerging Viral Diseases is the involved factors driving the appearance and spread of emerging viral diseases; the global health and economic impacts of recently emerging viral diseases in humans; preventive and curative measures for control of diseases.

We focus on various viral infections as top listed by WHO which includes clinical manifestations, factors affecting, treatment and preventive measures that have received increased attention during the past five years.

It need of hour to have better understanding of the basic requirements that lead to increased virus transmission between species and better viral replication in new species is needed to accurately assess the threat of a newly identified virus to the human population.

\section{Introduction}

We now live in a global village, closely linked through international travel, politics, economics, culture, humanhuman and human- animal interactions. These microbes causing emerging infectious diseases could potentially be used for bioterrorism, a grave concern. Hence all medical personnel should have at least a basic understanding of these emerging infectious diseases.

Examples of emerging viral infections at the international level include Ebola Haemorrhagic fever (in Zaire \& Gabon), Lassa fever (Sierra Leone), SARS, Avian Influenza, Zika Virus etc.

\section{Definition}

Emerging Viral infectious diseases are new, reemerging or drug resistant viral infections whose incidence in humans has increased within the past two decades or whose incidence threatens to increase in the near future [1].

\section{Factors Affecting}

\section{Human Ecology}

Remote areas of the world are now being colonized at a high frequency, driven by population pressures and economic motives, the harvest of valuable trees and exotic 
animals. The construction of new dams, roads, largecrowded cities and other alterations of the natural environment create new ecological niches.

\section{Deliberate Introduction of a Virus New to a Specific Population}

On occasion, a virus has been deliberately introduced into a susceptible population where it caused the emergence of an epidemic of various virus such as poxvirus, myxomatosis etc.

\section{Xenotransplantation}

In the worst scenario, this could enable a foreign virus to cross the species barrier and become established as a new human virus that might spread from the graft recipient to other persons [2].

\begin{tabular}{|c|c|c|}
\hline S. No & Factors & Determinant \\
\hline 1 & Human factors & $\begin{array}{l}\text { - Sexual activity } \\
\text { - Substance abuse }\end{array}$ \\
\hline 2 & Biological factors & $\begin{array}{l}\text { - Natural mutation } \\
\text { - Antimicrobial resistance } \\
\text { - Immunosuppression }\end{array}$ \\
\hline 3 & $\begin{array}{c}\text { Economic and } \\
\text { social development }\end{array}$ & $\begin{array}{l}\text { - Population growth, density, distribution } \\
\text { - Environmental changes such as deforestation, dam building, global warming } \\
\text { - Increased global travel\& international commerce, Bio-terrorism } \\
\text { - Agribusiness, food processing } \\
\text { - Wild-Life Trade/Ecotourism }\end{array}$ \\
\hline 4 & Poverty \& Social breakdown & $\begin{array}{l}\text { - Inadequate public health systems } \\
\text { - Open defecation } \\
\text { - Lack of safe water, war etc. }\end{array}$ \\
\hline
\end{tabular}

Table: List of Factors that Lead to Emergence of Viral Diseases.

Viruses enter the body through respiratory \&alimentary tract, skin, conjunctiva, genital tract, or parent to progeny etc [3].

\section{Emerging Viral Infectious Diseases}

Who's Top 8 Lists Of Disease Likely To Cause Severe Epidemics: Crimean-Congo Haemorrhagic Fever, Ebola, Marburg, Lassa Fever, Sars, Nipah, Rift Valley Fever Etc [4].

Crimean-Congohaemorrhagic Fever Is A Tick Borne Virus Primarily Found In Africa And Asia. It Causes Death Up To 40\% Of Cases And Has No Vaccine. In India It Found In Kolat, Gujarat , January 2011 [4].

\section{Severe Acute Respiratory Syndrome}

SARS is given to a severe atypical pneumonia has been occurring since $1 \mathrm{Feb}, 2003$. US centres for Disease control and prevention released a case definition which includes clinical criteria-Mild or moderate respiratory illness, temp $>100.4 \mathrm{~F}$ and evidences of pneumonia, RDS etc. Epidemiological criteria include close contact within 10 days of onset of symptoms with a person known or suspected to have SARS infection. There was another classifications of SARS-SARS-associated Coronavirus found.

Management of cases includes isolate the patient, perform diagnostic studies, provide treatment and all hygiene precaution should be followed as routine measures [3].

\section{Influenza Virus}

Avian Influenza: In mid Dec 2003, there was an outbreak of avian influenza in Asia caused by highly pathogenic H5N1 strain which has included fever, cough, nasal discharge etc. by birds.

Treatment \& prevention includes antiviral treatment, infection control measures, respiratory hygiene, immunization and dissemination of information [5].

H1N1 Influenza: first case with H1N1 influenza like illness was reported in Mexico on March 18,2009 which had included symptoms of acute respiratory distress including fever, cough, sore throat ,body pain etc. In India found in Hyderabad, Andhra Pradesh, May 2009 (First laboratory confirmed case identified). 


\section{Virology \& Immunology Journal}

Treatment is supportive which includes bed rest, increased fluid consumption, cough suppressant, antipyretics and analgesics [5].

Ebola virus saw severe outbreak in West Africa in 2014-15 and is often fatal if untreated. It is also known as Ebola haemorrhagic Fever, is a severe fatal illness in humans. It spread in human population through humanhuman.

It can be controlled by package of interventions namely case management, infection prevention \& control practices, surveillance, good laboratory services, safe and dignified burial and social mobilization etc $[4,6]$.

Lassa fever has a death rate of only 1 , with only 1 in 5 infections resulting in severe diseases where virus affects several organs. Around $80 \%$ of people who become infected with virus have no symptoms [6].

The *Nipah Virus was first identified in 1998 , and affects both humans and animals. In India found in Siliguri, West-Bengal (WB), 2001.There is no vaccine and treatment for humans is intensive supportive care [4].

Rift Valley fever also affects the humans, usually lasts up to seven days with the body fighting the virus without medical assistance and some people develop more severe form which can lead to death.

Severe fever with thrombocytopenia syndrome was first identified in rural China and as of 2014 there had been around 2500 reported cases, with a death rate of $7 \%$ [6].

\section{Zika Virus (2015)}

The final disease identified by WHO. Zika virus (ZIKV) is a member of the virus family Flaviviridae. It is spread by daytime-active Aedes mosquitoes. Symptoms may include fever, red eyes, joint pain, headache, and a maculopapular rash. Diagnosis is by testing the blood, urine, or saliva for the presence of Zika virus RNA when the person is sick.

Efforts to prevent bites include the use of insect repellent, covering much of the body with clothing, mosquito nets, and getting rid of standing water where mosquitoes reproduce.
It was officially declared a public health emergency on 1 Feb, 2016 following WHO mission in Brazil where the disease began to spread. The disease has been found in 61 countries and currently part of research and development programs to provide recommendations and potential diagnostics [7].

\section{Conclusion}

One of the goals of infectious viral diseases research is the development and production of countermeasures. We must develop partnership among clinicians, researchers, government and industry to detect \& diagnose diseases, to conduct basic countermeasures, to manufacture vaccines and drugs to prevent and treat diseases etc.

Today all medical and nursing students will play an important role in all aspects of our efforts to combat infectious Diseases. It is clear that we will heavily rely on fundamental science, its application, intellectual capital and researcher facilities to meet the challenge of microbes and humans.

\section{References}

1. Ananthanarayan R. Textbook of microbiology $8^{\text {th }}$ ed. universities press private limited: India Pp: 701-708.

2. Gerard TJ, Christine C, Berdell F. Microbiology $4^{\text {th }}$ (Edn.), The Benjamin Publishing Company, California Pp: 333-360.

3. Joseph M, Edward A, Ernest J. Review of Medical Microbiology 9th (Edn.), Lange Medical Publishers: California Pp: 303-370.

4. Paniker CKJ. Textbook of Microbiology $7^{\text {th }}$ (Edn.), Universities press: Hyderabad, India Pp: 430-582.

5. www.who.int/medicines/ebola-treatment/WHO-listof-top-emerging-diseases/en/

6. https://wwwnc.cdc.gov/eid/

www.sinobiological.com/zika-virus-virology.htm 